\section{Case Reports in Neurology}

Case Rep Neurol 2021;13:205-210

DOI: 10.1159/000513852

Published online: March 19, 2021
(C) 2021 The Author(s) www.karger.com/crn

This article is licensed under the Creative Commons Attribution-NonCommercial 4.0 International License (CC BY-NC) (http://www.karger.com/Services/OpenAccessLicense). Usage and distribution for commercial purposes requires written permission.

\title{
Frontotemporal Dementia with Parkinsonism and Epilepsy Associated with VGKC Antibodies: Case Report and Literature Review
}

\author{
Matthew Saint $^{a} \quad$ Vafa Alakbarzade $^{b} \quad$ Brendan McLean $^{b}$ \\ ${ }^{a}$ College of Medicine and Health, Exeter, UK; bepartment of Neurology, Royal Cornwall \\ Hospitals NHS Trust, Truro, UK
}

\section{Keywords}

Parkinsonism · Epilepsy · Frontotemporal dementia · Anti-VGKC antibodies · Cognitive dysfunction

\begin{abstract}
Antibodies directed against the voltage-gated potassium channel complex (anti-VGKCs) are implicated in several autoimmune conditions including limbic encephalitis and epilepsy. However, emerging evidence suggests that only specific subtypes of anti-VGKCs are pathogenic. We present the case of a 55-year-old man who initially presented with focal unaware seizures and behavioural changes mimicking anti-VGKC-seropositive encephalitis that further progressed to parkinsonism with evidence of frontotemporal dementia and pre-synaptic dopaminergic deficit. Aggressive treatment with immunotherapy was ineffective, and antibody subtyping later revealed the anti-VGKC antibodies to be negative for leucine-rich glioma-associated 1 (LGI1) and contactin-associated protein-like 2 (CASPR2) - the two known pathogenic subtypes. The clinical relevance of so-called "double-negative" anti-VGKCs (i.e., those not directed towards LGI1 or CASPR2) has been called into question in recent years, with evidence to suggest they may be clinically insignificant. Our case emphasises the importance of antibody subtyping in cases of anti-VGKC seropositivity; negative results, particularly when combined with a poor response to immunotherapy, should prompt a rapid reconsideration of the working diagnosis.




\section{Case Reports in Neurology}

Case Rep Neurol 2021;13:205-210

DOI: 10.1159/000513852

(c) 2021 The Author(s). Published by S. Karger AG, Basel www.karger.com/crn

Saint et al.: Anti-VGKC Antibodies: The Importance of Affinity Subtyping

\section{Case Description}

A 55-year-old man presented with a 12-month history of persistent headache, global memory decline, partial anosmia, and infrequent "vacant" episodes of 5-30 min duration; described as transient states of altered awareness without involuntary movements. Attacks were usually followed by a state of somnolence or disorientation. His past medical history was unremarkable, and his only medication was a H2-receptor antagonist. Family history included epilepsy in his two siblings. Initial examination revealed only partial alopecia of eyelashes and brows which had manifested 6 months prior to presentation. The initial set of investigations were non-diagnostic and included brain magnetic resonance imaging (MRI) and $24 \mathrm{~h}$ ambulatory electroencephalogram (EEG) which did not capture a typical ictus.

Over the subsequent months, the vacant episodes increased in frequency and became associated with a peculiar gustatory perception, confabulations and involuntary paroxysmal jerky movements. Additionally, neuropsychiatric disturbances manifested including personality/affective changes with persistent suicidal ideation and deliberate self-harm that progressed rapidly. His partner also described classical rapid eye movement sleep disorder (RBD) around this time. A repeat ambulatory 24-h EEG revealed seizure activity stemming from a temporal lobe focus associated with a typical ictus. Voltage-gated potassium channel (VGKC) complex antibodies were found to be strongly positive ( $410 \mathrm{pmol} / \mathrm{L}$; normal range $0-69$ ) with subtyping being available later. Subtyping was not performed on this sample. Surveillance body computed tomography did not reveal an occult neoplasm. Management for presumed anti-VGKC complex encephalitis was commenced including pulsed methylprednisolone (500 mg daily for 5 days) followed by a slow tail. Lamotrigine was initiated and up-titrated to maximal dose to manage focal unaware seizures, although response remained partial. Neuropsychiatric disturbances were also intractable, and so subsequently he had a trial of rituximab with no response.

Over 53 months after initial presentation, the clinical spectrum of breakthrough focal unaware seizures, progressive myoclonic jerks, cognitive and affective dysfunction was extended to an extrapyramidal syndrome. Mobility declined precipitously over a 6-month period to the point that the patient was unable to walk and became reliant upon a wheelchair. He developed an asymmetrical resting hand tremor and severe postural imbalance over the subsequent 6 months. Neurological examination revealed normal ocular movements and limb tone, but bradykinesia with atypical festinant and slow gait. Metoclopramide prescribed for dizziness and nausea was promptly discontinued. A dopamine transporter (DaT) scan demonstrated a bilateral reduction in tracer uptake in both putamina, which was more marked on the left with some reduction in the head of the left caudate nucleus (Fig. 1). Repeat anti-VGKC complex antibody level was $147 \mathrm{pmol} / \mathrm{L}$, but leucine-rich glioma inactivated 1 (LGI1) and contactin-associated protein-like 2 (CASPR2) were negative. Brain MRI performed 90 months after initial presentation demonstrated early frontotemporal atrophy with no white matter change or other abnormality (Fig. 2). His Addenbrooke's cognitive examination revealed significant decline in visuospatial attention, memory, and attention domains (70/100). Neither a course of rituximab nor dopaminergic treatment was effective. With a clinical pattern suggestive of a frontotemporal dementia (FTD), genetic testing was undertaken including FUS, GRN, $M A P T$, and $P R N P$, but no recognised disease-causing variant was identified.

\section{Karger'=}




\section{Case Reports in Neurology}

Case Rep Neurol 2021;13:205-210

DOI: $10.1159 / 000513852$

(c) 2021 The Author(s). Published by S. Karger AG, Basel www.karger.com/crn

Saint et al.: Anti-VGKC Antibodies: The Importance of Affinity Subtyping

\section{Discussion}

We present the case of a 55-year-old man with progressive focal unaware seizures and behavioural changes, initially diagnosed and treated as a VGKC antibody-seropositive encephalitis that further progressed to parkinsonism with an evidence of FTD and pre-synaptic dopaminergic deficit. Serum VGKC antibodies were positive but titres were never considered high. Moreover, when available, the serum CASPR2 and LGI1 were negative. The utility and significance of VGKC seropositivity in these so-called "double-negative" patients has been questioned in recent years [1-3], particularly after it was found in one study that $5 \%$ of controlled subjects were seropositive for double-negative VGKC antibodies [4]. Several reports have suggested that these double-negative VGKC antibodies may actually be intrinsically nonpathogenic and thus clinically insignificant $[1,2,5]$. Whereas the clinical phenotypes associated with CASPR2 and LGI1 autoantibodies are well described and reproducible [6], the great heterogeneity of double-negative presentations raises the question as to whether these patients actually have a common disease entity at all [2]. Certainly, the greatly reduced response rates of double-negative patients to conventional immunotherapies in comparison to CASPR2 and LGI1-seropositive patients is suggestive of a non-autoimmune aetiology [2].

Our patient also developed parkinsonian signs 4.5 years after initial presentation. It would be atypical to develop a parkinsonian disorder at a later stage of immune-related disease, especially after aggressive treatment with steroids and immunotherapy [7-9]. The extrapyramidal signs are always observed around the time of initial presentation [10-12]. There are some cases with CASPAR2 antibodies in a parkinsonian presentation in the context of a more florid encephalopathy or concomitant neuromyotonia $[9,11]$.

Cognitive decline in our patient had a bvFTD pattern. Moreover, his brain MRI showed mild asymmetric frontoparietal atrophy. FTD associated with parkinsonism was linked to corticobasal degeneration (CBD), progressive supranuclear palsy (PSP) and FTDP-17. These atypical parkinsonism cases are non-responsive to L-dopa and may result in pre-synaptic dopaminergic deficit as evidenced by DaT scan [13-16]. Probable CBD clinical criteria require insidious onset and gradual progression with symptom duration of at least 1 year, age at onset $\geq 50$ years, asymmetric presentation of either limb rigidity or akinesia, or limb dystonia, or limb myoclonus plus either orobuccal or limb apraxia, or cortical sensory deficit, or alien limb phenomena (more than simple levitation) [17]. However, there are no case reports of CBD and epilepsy. Absence of hypophonic speech, dysphagia and impaired ocular movement in our patient reduce the possibility of PSP.

The term "FTD and parkinsonism linked to chromosome 17" (FTDP-17) stems from a consensus conference in 1996 and relates to families with FTD inherited in an autosomal dominant mode later shown to be due to mutations in MAPT or GRN, both located on chromosome 17. These patients usually present with bvFTD and parkinsonism with an early age at onset. The pathology is different in FTDP-17 due to MAPT mutations (tauopathy) versus FTDP-17 due to GRN mutations (TDP-43 proteinopathy) [18]. The cumulative probability of developing seizures after FTD onset is low, up to $3 \%$, and relative seizure rates increased with earlier age at onset in FTD (age <50, 53-fold; 50-69, 9-fold) [19]. Overexpression of tau with mutations linked to FTD or the A152T variant, which is linked to several tauopathies, has been shown to increase seizure susceptibility in transgenic mice [20,21]. However, our targeted sequencing did not reveal a pathogenic variant, raising suspicion of possible different genetic or epigenetic mechanisms.

\section{Karger'=}




\section{Case Reports in Neurology}

\begin{tabular}{l|l}
\hline Case Rep Neurol 2021;13:205-210 \\
\hline DOI: 10.1159/000513852 & $\begin{array}{l}\text { @ 2021 The Author(s). Published by S. Karger AG, Basel } \\
\text { www.karger.com/crn }\end{array}$ \\
\hline
\end{tabular}

Saint et al.: Anti-VGKC Antibodies: The Importance of Affinity Subtyping

\section{Conclusion}

Positive VGKC antibodies were a red herring in the present case and deflected our management towards immunotherapy which had no benefit. The subsequent subtype analysis revealing negative LGI1 and CASPR2 in the context of positive VGKC indicated that this was not a true marker of an immunotherapy-responsive disorder and should alert clinicians to search for alternative diagnoses. The subsequent development of parkinsonism and a bvFTD phenotype with pre-synaptic dopaminergic deficits raises the possibility of FTDP-17 despite the negative genetic testing so far.

\section{Statement of Ethics}

Written informed consent was obtained from the patient for publication of this case report and any accompanying images.

\section{Conflict of Interest Statement}

The authors have no conflicts of interest to declare.

\section{Funding Sources}

No funding sources were solicited in the development of the manuscript.

\section{Author Contributions}

M.S. wrote the manuscript, V.A. and B.M. reviewed, edited, and approved the final version of the manuscript.

\section{References}

1 Paterson RW, Zandi MS, Armstrong R, Vincent A, Schott JM. Clinical relevance of positive voltage-gated potassium channel (VGKC)-complex antibodies: experience from a tertiary referral centre. J Neurol Neurosurg Psychiatry. 2014 Jun;85(6):625-30.

2 Lang B, Makuch M, Moloney T, Dettmann I, Mindorf S, Probst C, et al. Intracellular and non-neuronal targets of voltage-gated potassium channel complex antibodies. J Neurol Neurosurg Psychiatry. 2017 Apr;88(4):353-61.

3 Pettingill P, Kramer HB, Coebergh JA, Pettingill R, Maxwell S, Nibber A, et al. Antibodies to GABAA receptor $\alpha 1$ and $\gamma 2$ subunits: clinical and serologic characterization. Neurology. 2015 Mar;84(12):1233-41.

4 Vincent A, Buckley C, Schott JM, Baker I, Dewar BK, Detert N, et al. Potassium channel antibody-associated encephalopathy: a potentially immunotherapy-responsive form of limbic encephalitis. Brain. 2004 Mar;127(Pt 3):701-12.

5 van Sonderen A, Schreurs MW, de Bruijn MA, Boukhrissi S, Nagtzaam MM, Hulsenboom ES, et al. The relevance of VGKC positivity in the absence of LGI1 and Caspr2 antibodies. Neurology. 2016 May;86(18):1692-9.

6 Montojo MT, Petit-Pedrol M, Graus F, Dalmau J. Clinical spectrum and diagnostic value of antibodies against the potassium channel related protein complex. Neurologia. 2015 Jun;30(5):295-301.

\section{Karger's}




\section{Case Reports in Neurology}

\begin{tabular}{l|l}
\hline Case Rep Neurol 2021;13:205-210 \\
\hline DOI: 10.1159/000513852 & $\begin{array}{l}\text { @ 2021 The Author(s). Published by S. Karger AG, Basel } \\
\text { www.karger.com/crn }\end{array}$ \\
\hline
\end{tabular}

Saint et al.: Anti-VGKC Antibodies: The Importance of Affinity Subtyping

7 Shin YW, Lee ST, Shin JW, Moon J, Lim JA, Byun JI, et al. VGKC-complex/LGI1-antibody encephalitis: clinical manifestations and response to immunotherapy. J Neuroimmunol. 2013 Dec;265(1-2):75-81.

8 Radja GK, Cavanna AE. Treatment of VGKC complex antibody-associated limbic encephalitis: a systematic review. J Neuropsychiatry Clin Neurosci. 2013;25(4):264-71.

9 Tan KM, Lennon VA, Klein CJ, Boeve BF, Pittock SJ. Clinical spectrum of voltage-gated potassium channel autoimmunity. Neurology. 2008 May;70(20):1883-90.

10 Molloy A, Cassidy E, Ryan A, O OT. VGKC positive autoimmune encephalopathy mimicking dementia. BM] Case Rep. 2011;2011.

11 Kurtis MM, Toledano R, García-Morales I, Gil-Nagel A. Immunomodulated parkinsonism as a presenting symptom of LGI1 antibody encephalitis. Parkinsonism Relat Disord. 2015 Oct;21(10):1286-7.

12 Kannoth S, Nambiar V, Gopinath S, Anandakuttan A, Mathai A, Rajan PK. Expanding spectrum of contactinassociated protein 2 (CASPR2) autoimmunity-syndrome of parkinsonism and ataxia. Neurol Sci. 2018 Mar;39(3):455-60.

13 Djang DS, Janssen MJ, Bohnen N, Booij J, Henderson TA, Herholz K, et al. SNM practice guideline for dopamine transporter imaging with 123I-ioflupane SPECT 1.0. J Nucl Med. 2012 Jan;53(1):154-63.

14 Poewe W, Scherfler C. Role of dopamine transporter imaging in investigation of parkinsonian syndromes in routine clinical practice. Mov Disord. 2003 Oct;18(S7 Suppl 7):S16-21.

15 Perju-Dumbrava LD, Kovacs GG, Pirker S, Jellinger K, Hoffmann M, Asenbaum S, et al. Dopamine transp orter imaging in autopsy-confirmed Parkinson's disease and multiple system atrophy. Mov Disord. 2012 Jan;27(1):65-71.

16 Carecchio M, Galimberti D, Fenoglio C, Serpente M, Scarpini E, Comi C, et al. Evidence of pre-synaptic dopaminergic deficit in a patient with a novel progranulin mutation presenting with atypical parkinsonism. J Alzheimers Dis. 2014;38(4):747-52.

17 Armstrong MJ, Litvan I, Lang AE, Bak TH, Bhatia KP, Borroni B, et al. Criteria for the diagnosis of corticobasal degeneration. Neurology. 2013 Jan;80(5):496-503.

18 Deutschländer AB, Ross OA, Dickson DW, Wszolek ZK. Atypical parkinsonian syndromes: a general neurologist's perspective. Eur J Neurol. 2018 Jan;25(1):41-58.

19 Beagle AJ, Darwish SM, Ranasinghe KG, La AL, Karageorgiou E, Vossel KA. Relative Incidence of Seizures and Myoclonus in Alzheimer's Disease, Dementia with Lewy Bodies, and Frontotemporal Dementia. J Alzheimers Dis. 2017;60(1):211-23.

20 García-Cabrero AM, Guerrero-López R, Giráldez BG, Llorens-Martín M, Avila J, Serratosa JM, et al. Hyperexcitability and epileptic seizures in a model of frontotemporal dementia. Neurobiol Dis. 2013 Oct;58:200-8.

21 Maeda S, Djukic B, Taneja P, Yu GQ, Lo I, Davis A, et al. Expression of A152T human tau causes agedependent neuronal dysfunction and loss in transgenic mice. EMBO Rep. 2016 Apr;17(4):530-51. 
Case Reports in Neurology

\begin{tabular}{l|l}
\hline Case Rep Neurol 2021;13:205-210 \\
\hline DOI: 10.1159/000513852 & $\begin{array}{l}\text { @ 2021 The Author(s). Published by S. Karger AG, Basel } \\
\text { www.karger.com/crn }\end{array}$ \\
\hline
\end{tabular}

Saint et al.: Anti-VGKC Antibodies: The Importance of Affinity Subtyping

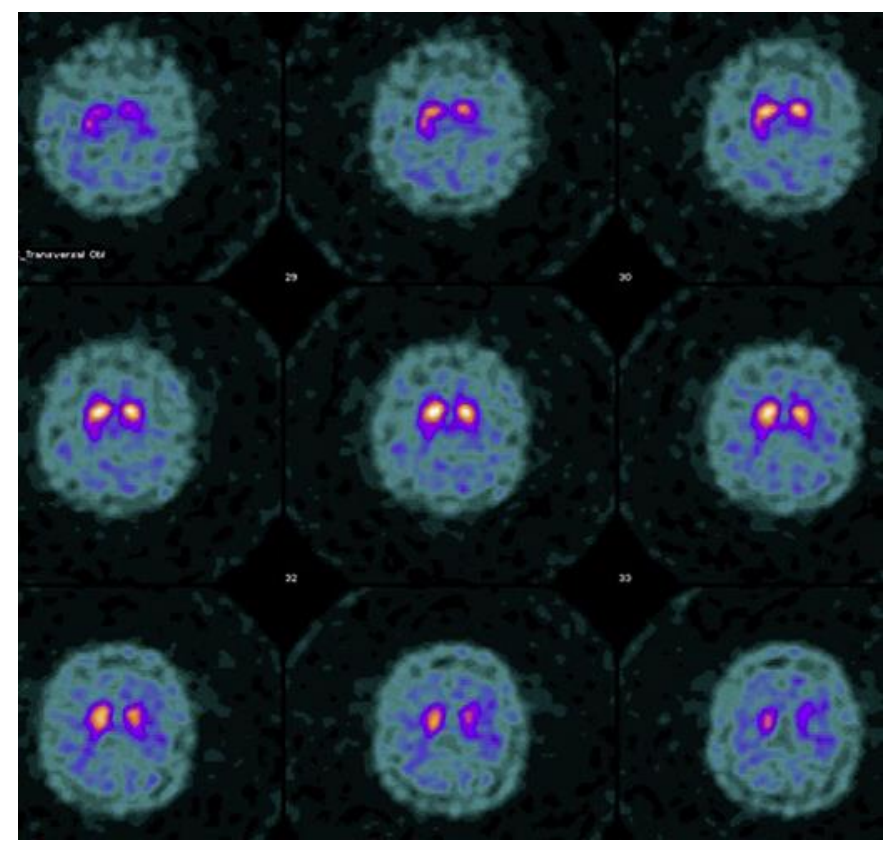

Fig. 1. Brain dopamine transporter study. Reduction of tracer uptake in the putamen on both sides, more marked on the left. Slightly reduced relative uptake of tracer in the head of the caudate nucleus on the left.
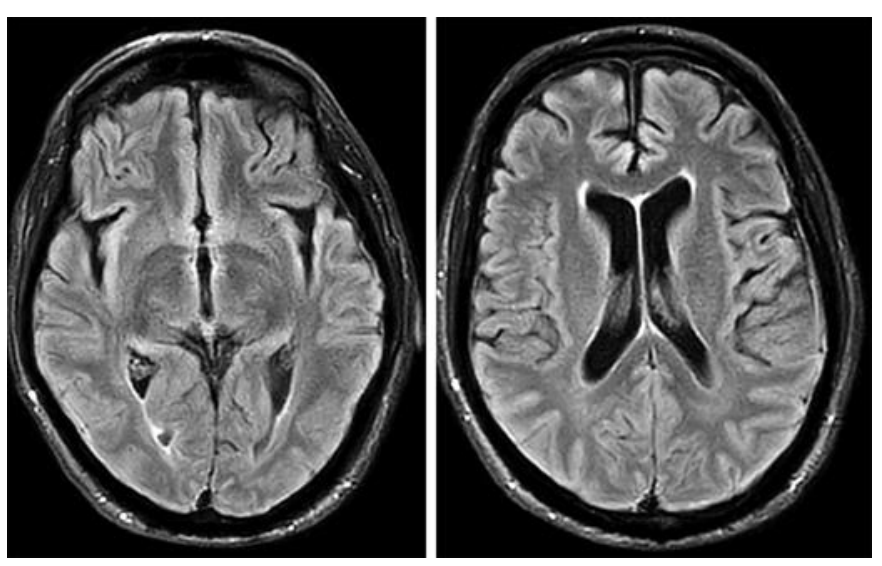

Fig. 2. Brain MRI. Cerebral atrophy predominantly involving the frontal and the temporal lobes. 